\title{
Farmers' Participation in Irrigation Management in the Punggur Utara Irrigation Area, Indonesia
}

\section{Dyah Indriana Kusumastuti*, Vera Chania Putri, Dwi Jokowinarno and Endro Prasetyo Wahono}

Department of Civil Engineering, Engineering Faculty, University of Lampung, Jl. Sumantri Brojonegoro No.1, Bandar Lampung 35145, Indonesia

\begin{abstract}
Farmers' participation in water resource management in Indonesia has been accommodated through Law No. 7/2004 and Government Regulation No. 20/2006 regarding irrigation. In government regulations, farmers' participation in irrigation water management has been described in detail, with one of the components of irrigation network management being operations and maintenance. Most irrigation system problems are related to irrigation networks. Farmers' participation in the Water Users Association (WUA), a farmer institution responsible for managing and developing irrigation networks at the tertiary level, determines how irrigation network management activities are carried out. The purpose of this study was to determine the effect of the socio-economic characteristics of farmers and of group participation of a WUA in carrying out irrigation management activities in operations and maintenance activities. The result is connected to the physical condition of the irrigation network. The research took place in the village of Sumber Rejo in the Punggur Utara irrigation area, which is in Lampung Province, Indonesia, and is where WUA Harapan Maju is active. Samples were

ARTICLE INFO

Article history:

Received: 07 September 2020

Accepted: 25 November 2020

Published: 30 April 2021

DOI: https://doi.org/10.47836/pjst.29.2.02

$\overline{\text { E-mail addresses: }}$

kusumast@gmail.com (Dyah Indriana Kusumastuti)

chania.vera@yahoo.com (Vera Chania Putri)

d.jokowinarno@gmail.com (Dwi Jokowinarno)

epwahono@eng.unila.ac.id (Endro Prasetyo Wahono)

* Corresponding author determined based on a random sampling method, which found that the sample size required for the study was 80 farmers. The results show that of socio-economic factors, the most influential is the number of farmers' dependents, followed by the land area owned by each farmer. It was also found that group participation of WUA Harapan Maju
\end{abstract}


was categorised as "barely" adequate. This result was confirmed by the condition of the irrigation system in the Punggur Utara irrigation area, which was also "barely" adequate, and the system's operations and maintenance needed to be improved.

Keywords: Farmer, group participation, irrigation management, operations and maintenance, WUA

\section{INTRODUCTION}

Irrigation management plays an important role in agriculture, as irrigation is a key factor that may affect farmer productivity (Azhar et al., 2014; Carracelas et al., 2019; Dirwai et al., 2019; Hudzari et al., 2016; Mateos et al., 2002; Meena et al., 2019; Valipour, 2014). In developing countries, irrigation management systems have not performed well in the past because their management was entirely (and poorly) controlled by governments (Abernethy, 2010). Due to weak institutional arrangements, maintenance cannot be performed optimally, which causes both physical infrastructure and infrastructure management to deteriorate. These problems have impacted efficient and timely water delivery and farmer productivity in turn.

Since the 1980s, instruments of reform have been implemented in many developing countries (Alaerts, 2020; Baldwin et al., 2016; Mollinga \& Bolding, 2004; Sehring, 2007). The most significant paradigm of these reforms is a shift from construction and rehabilitation to operations and maintenance, which can improve infrastructure conditions (Suhardiman \& Giordano, 2014). To improve infrastructure conditions in Indonesia, the reforms introduced the formation of Water Users Associations (WUAs) (Gany et al., 2019). These involve farmers in system management and irrigation management transfer, thereby allowing farmers greater control and responsibility (Mukherji et al., 2009).

Irrigation management transfer is a reform package aimed at full or partial devolvement of irrigation management responsibilities from the government to farmers themselves through the establishment of WUAs (FAO, 2007; Mukherji et al., 2009). Participatory irrigation management and irrigation management transfer became the national irrigation strategies for most developing countries and are considered the best solution for irrigation management in developing countries (Fulazzaky, 2017; Poddar et al., 2011).

In irrigation management, it is vital to perform collective actions based on farmers' collaborative efforts or cooperation in WUAs. Even so, the results are mixed. Some cases of collective action for irrigation management face difficulties (Letsoalo \& Van Averbeke, 2004; Moustafa, 2004), whereas other cases are successful (Ghosh et al., 2019; Huamanchumo et al., 2008; Rap, 2006; Vandersypen et al., 2008).

In Indonesia, the farmers' participatory approach to water resource management has been accommodated by Law No. 7/2004. In compliance with the terms of article 41 of Law No. 7/2004, Government Regulation No. 20/2006 (PP No. 20/2006) on irrigation 
has formulated a more detailed description of farmers' participation in irrigation water management. One of the components of the irrigation networks scheme management is operations and maintenance and is related to the daily activities of farmers on their irrigated lands. Such activities target reducing government subsidies, improving water-use efficiency, and improving annual food production (Fulazzaky, 2017).

Farmers are the main actors in all operational activities and irrigation maintenance. In carrying out the series of activities involved in irrigation, individual farmers are influenced by many factors, one being farmers' socio-economic characteristics. These characteristics include age, education level, duration of farming, the position of the farmer in the organisation, family size, land area, and income level (Khalkheili \& Zamani, 2009). Apart from these characteristics, another influential element in a series of operations and maintenance activities is the group dynamics of the WUA. Therefore, in this study, the effect of farmers' socio-economic aspects, as well as the dynamics of a WUA are reviewed to understand the effect of operations and maintenance activities, both in physical and nonphysical terms. The study is conducted by distributing questionnaire to the group members to gather the information about the socio-economic characteristics of the farmers as well as data collection and field observation to assess the physical condition of the irrigation network.

\section{WUA Group Participation}

Within a WUA group, cooperation among farmers is necessary to determine and influence the behaviour of the group and its members to effectively achieve the group's aims. Achieving group aims depends on the energy and creativity of members in carrying out their activities. In other words, the development of farmer groups depends on the internal dynamics of the groups, which are determined by the group members. Assessing group dynamics means assessing the strength contained in a group, as this determines group behaviour and group members' ability to achieve the group's goals. Ghosh et al. (2019) used several parameters to assess the group dynamics of some WUAs in India, such as group participation, decision-making procedures, group atmosphere, empathy, interpersonal trust, and social support. Supriyadi (2008) conducted similar research in the Polokarto District, Sukoharjo Regency, Central Java Province, Indonesia. Supriyadi's study found that group dynamics such as group goals, group structure, task functions, coaching and maintenance, cohesiveness, and pressure within the group were related to operations and maintenance of irrigation infrastructure. In contrast, the effectiveness of the group and its hidden agenda were unrelated to operations and maintenance of irrigation infrastructure. Other research was conducted by Desrimon and Fiatno (2018) on the influence of social and economic aspects on operations and maintenance. This research found that social, economic, and institutional factors simultaneously influence aspects of operations and 
maintenance. These findings have motivated the current researchers to investigate irrigation system management in terms of the socio-economic part. In addition to this, the influence of aspects of a WUA in terms of group participation towards operational activities and maintenance of irrigation networks will be investigated.

\section{METHODS}

This research was conducted in the Punggur Utara irrigation area, located in the village of Sumber Rejo in the Kota Gajah district of the Central Lampung Regency. The Punggur Utara irrigation area is part of the Sekampung irrigation system area, located at coordinates $105^{\circ} 28^{\prime} \mathrm{E}-105^{\circ} 33^{\prime} \mathrm{E}$ and $4^{\circ} 54^{\prime} \mathrm{S}-5^{\circ} 01^{\prime} \mathrm{S}$ (Figure 1). Irrigation water for this area is conveyed through the Argoguruh Dam, which uses the Sekampung River. Argoguruh's weir is located at coordinates $5^{\circ} 11^{\prime} 57^{\prime \prime} \mathrm{S}-105^{\circ} 10^{\prime} 46^{\prime} \mathrm{E}$.

The Punggur Utara irrigation area consists of 26 units, and this study focused on one of them: Unit 15, otherwise known as BPU 15 (BPU stands for Punggur Utara structures in its Indonesia language). This unit passes through five villages (Sumber Rejo, Purwo Rejo,



Figure 1. Study area 
Bangun Rejo, Buyut Ilir, and Buyut Utara), and each village is managed by a WUA. This research was conducted in the village of Sumber Rejo, where the potential and functional areas of paddy rice fields are 304 ha and 238 ha, respectively.

\section{WUA Harapan Maju at Sumber Rejo Village}

WUA Harapan Maju already has a legitimate organisational structure, consisting of a chairman, secretary, treasurer, and an irrigation water distribution regulator who has different duties and responsibilities. The position, status, and role of the caretaker, along with other group members, is described in detail in the group's organisational structure. In this study, the group participation of WUA Harapan Maju was studied. A questionnaire was distributed to group members and included several assessment categories that aimed to represent group participation.

The sample was determined using the probability sampling method (random sample), with a cluster sampling technique. Samples were taken from the distribution of tertiary channels in Sumber Rejo Village. Then, as many samples as were needed were randomly drawn from the cluster. The number of farmers who joined the WUA Harapan Maju, Sumberejo Village is 434. To determine the number of samples to be examined, the Slovin formula was used, and by assuming a margin error of $10 \%$, the sample size obtained was 80 farmers.

\section{Variable}

In this research, independent variables consist of some socio-economic characteristics of the farmers, and the dependent variable consists of operational and maintenance irrigation (Table 1).

Table 1

Dependent and independent variables

\begin{tabular}{|c|c|}
\hline Independent variable $(X)$ & Dependent variable (Y) \\
\hline \begin{tabular}{ll}
\multicolumn{2}{l}{ Individual Farmers' Characteristics } \\
- & Age $\left(\mathrm{X}_{1}\right)$ \\
$\cdot$ & Level of Education $\left(\mathrm{X}_{2}\right)$ \\
$\cdot$ & Farming experience $\left(\mathrm{X}_{3}\right)$ \\
$\cdot$ & Size of Land $\left(\mathrm{X}_{4}\right)$ \\
- & Number of Family Dependents $\left(\mathrm{X}_{5}\right)$ \\
$\cdot$ & Income $\left(\mathrm{X}_{6}\right)$
\end{tabular} & Irrigation management $(\mathrm{Y})$ \\
\hline $\begin{array}{l}\text { Group Characteristics } \\
\text { - Group Participation }\left(\mathrm{X}_{7}\right)\end{array}$ & \\
\hline
\end{tabular}




\section{Group Participation Criteria}

In this research, group dynamics focus on group members' participation, with indicators of group participation shown in Table 2. These indicators include participation in group goals, participation in group activities, participation in decision making and participation in interaction. Table 3 presents variables of irrigation management, including irrigation channel network, irrigation structure, maintenance, irrigation water, frequency of water distribution, and suitability of the schedule of water distribution.

Before doing further analysis, validity and reliability tests were performed to evaluate the accuracy and precision of the variables, as well as the consistency and stability of the questionnaire. The result of the validity test for variables 1 to 7 (representing farmers' age, farmers' education, farmers' dependents, farmers' experience, farmers' land area, farmers' income, and group participation respectively) shows that $t_{\text {computed }}$ values for most variables are larger than $t_{\text {table }}$ values, so that the results of the validity test are valid, except for variable 1, farmers' age. Furthermore, the reliability test found that $\mathrm{R}_{\text {computed }}$ is 0.3425 , which is larger than $\mathrm{R}_{\text {table, }}$ meaning that the questionnaire is consistent and robust.

Each of the seven variables is grouped into three categories and scored 1 to 3 in the ascending order. For example, level of education (X2) is grouped into elementary school, junior high school, and senior high school and higher. For analysis purpose, it is given the scores of 1, 2 and 3 for elementary school, junior high school, and senior high school and higher, respectively. Likert scale is used in the analysis using the scores of 1, 2 and 3 assigned to be poor, adequate, and good, respectively. Correlation analysis between variables is analysed using the Pearson product moment. Then multiple linear regression analysis is applied to quantify the strength of the relationship between the dependent and the independent variables.

Table 2

Variables of group participation

\begin{tabular}{lllc}
\hline Variable & & \multicolumn{1}{c}{ Indicator } & Number of questions \\
\hline Group & a. & Participation in group goals & 7 \\
Participation & b. & Participation in group activities & 11 \\
& c. & Participation in decision making & 7 \\
& d. & Participation in interaction & 3 \\
\hline
\end{tabular}

Table 3

Variables of irrigation management

\begin{tabular}{lll}
\hline Variable & & \multicolumn{1}{c}{ Indicator } \\
\hline Irrigation & a. & Irrigation channel network \\
Management & b. & Irrigation structure \\
& c. & Maintenance \\
& d. & Irrigation water \\
& e. & Frequency of water distribution \\
& f. & Suitability of the schedule of water distribution \\
\hline
\end{tabular}




\section{RESULTS AND DISCUSSION}

\section{Characteristics of Respondents}

Based on the calculation of the sample required, 80 respondents participated in this study. The farmers' answers on the questionnaire are classified into three categories for each variable. Age is one aspect of demographic characteristics that can influence participants' activities. It is known from the questionnaire that the youngest respondent is 22 years old, and the oldest is 76 years old. The average age of respondents in the village of Sumberejo is 49.3 years old. Based on the division of farmers' interval categories, the percentage of farmers aged between $21-40,41-59$, and $60-80$ years old is $30 \%, 42.5 \%$, and $27.5 \%$ respectively. The survey suggests that the highest percentage being $42.5 \%$ for the interval of 41-59 years old.

Farmers dependents are classified into three categories (i.e., 0-2 children, 3-4 children, and 5-6 children). It was found from the questionnaire that the largest percentage is $61.25 \%$ for farmers having 3-4 children, and the smallest percentage is $15 \%$ for farmers having 0-2 children. It can be said that the middle category, with 3-4 children, makes up most farmers' dependents.

The education levels of the respondents are classified into three categories (i.e., elementary school, junior high school, and senior high school and higher). The survey found that the largest percentage of respondents were formally educated until elementary school (48.75\%), while the smallest percentage of respondents were educated until senior high school or higher $(21.25 \%)$. This means that the farmers participating in WUA Harapan Maju still have a low level of education.

The farming experience of the respondents is divided into three categories (2-21 years, 22-41 years, and 42-60 years), with the highest percentage being 47\% for $2-21$ years' experience in farming, and the lowest being $25 \%$ for farmers having $42-60$ years' experience in agriculture. The results suggest that most farmers have the least amount of farming experience (i.e., between 2 to 21 years).

The land area owned by respondents is classified into three categories. The percentages for land areas of $0.125-0.425 \mathrm{ha}, 0.426-0.726 \mathrm{ha}$, and $\geq 0.727$ ha are $33.75 \%, 32.5 \%$, and $33.75 \%$ respectively. It is observed that there is no significant difference in the percentage of the land area owned by respondents.

The level of income is divided into three categories: $<\mathrm{Rp} 2,000,000$ per month,


percentage is $61.25 \%$ (i.e., farmers with income from farming of $<\mathrm{Rp} 2,000,000$, while the smallest percentage is $10 \%$ for farmers with farm income $\geq \mathrm{Rp} 5,000,000)$. It was found that farmers joining WUA Harapan Maju are still in the category of having a low farming income.

The result of farmers' characteristics in WUA Harapan Maju, Sumber Rejo Village, Kota Gajah District, Central Lampung Regency is shown in Table 4. 
Table 4

Résumé of farmers 'characteristics

\begin{tabular}{|c|c|}
\hline Category & Percentage \\
\hline \multicolumn{2}{|l|}{ Age in years $\left(X_{1}\right)$} \\
\hline $22-0$ & 30 \\
\hline $41-59$ & 42.5 \\
\hline $60-76$ & 27.5 \\
\hline \multicolumn{2}{|l|}{ Level of education $\left(\mathrm{X}_{2}\right)$} \\
\hline Elementary School & 48.75 \\
\hline Junior High School & 30 \\
\hline$\geq$ Senior High School & 21.25 \\
\hline \multicolumn{2}{|l|}{ Farming experience (years) $\left(\mathrm{X}_{3}\right)$} \\
\hline $2-21$ & 47.5 \\
\hline $22-41$ & 27.5 \\
\hline $42-60$ & 25 \\
\hline \multicolumn{2}{|l|}{ Size of Land $\left(\mathrm{X}_{4}\right)$} \\
\hline $0.125-0.425$ & 33.75 \\
\hline $0.426-0.726$ & 32.5 \\
\hline$\geq 0.727$ & 33.75 \\
\hline \multicolumn{2}{|l|}{ Number of family dependents $\left(\mathrm{X}_{5}\right)$} \\
\hline $0-2$ & 15 \\
\hline $3-4$ & 61.25 \\
\hline $5-6$ & 23.75 \\
\hline \multicolumn{2}{|l|}{ Income in rupiahs $\left(\mathrm{X}_{6}\right)$} \\
\hline$<\mathrm{Rp} 2,000,000$ & 61.25 \\
\hline $\mathrm{Rp}, 2000,000-\mathrm{Rp} 4,900,000$ & 26.25 \\
\hline$\geq$ Rp. $5,000,000$ & 12.50 \\
\hline
\end{tabular}

\section{Farmers' Participation in WUA Harapan Maju}

Based on the 28-question survey, the respondents' highest total score was 67 , and the lowest was 41, with an average score of 58. Table 5 shows the scores for each variable in Group Participation. Based on that result, the farmers' participation in WUA Harapan Maju, Sumber Rejo Village is "barely" adequate. Farmers care about the group's goals, and farmers interact well, which is shown by the scores of 2.580 and 2.325 for the variable's

Table 5

Average score for the group participation of WUA Harapan Maju

\begin{tabular}{lccc}
\hline Group Participation & Av. Total Score & Std Dev. & Average Score \\
\hline Goal & 18 & 1.925 & 2.580 \\
Activities & 18 & 3.700 & 1.636 \\
Decision Making & 15 & 2.597 & 2.107 \\
Interaction & 7 & 1.302 & 2.325 \\
\hline
\end{tabular}

Remarks: responses are weighted 1-3 (from poor to good) 
"goal" and "interaction", respectively. In decision making, the participation of farmers is sufficient, as evidenced by the score of 2.107 . However, only some farmers are actively involved in all operations and maintenance activities, which is shown by the average score of 1.636 for the "activities" variable.

\section{Irrigation Management}

Regarding irrigation management, some aspects respondents were asked about include the performances of the irrigation channel network; irrigation structures; maintenance of the irrigation channel and structures; sufficiency of irrigation water for paddy fields; sufficiency of water distribution during one planting period; and suitability of water distribution with the predetermined schedule. Table 6 presents the average scores of the variables in irrigation management. The scores which have scores greater than 2 are "maintenance", followed by "frequency of water distribution", while other variables score less than 2. In general, farmers believe that the irrigation management needs to be improved shown by the average score of all variables, 1.875, which is categorised as "barely" adequate.

Table 6

Average score of irrigation management

\begin{tabular}{lcc}
\hline Operations and Maintenance & Standard Deviation & Average Score \\
\hline Irrigation channel network & 0.600 & 1.763 \\
Irrigation structures & 0.569 & 1.575 \\
Maintenance & 0.656 & 2.489 \\
Irrigation water & 0.613 & 1.438 \\
Frequency of water distribution & 0.792 & 2.175 \\
Suitability of the schedule & 0.828 & 1.813 \\
\hline
\end{tabular}

Remarks: responses are weighted 1-3 (from poor to good)

\section{Irrigation Network in Sumber Rejo Village}

The existing condition of primary and secondary irrigation channels in the Punggur Utara irrigation area is mostly made of permanent structures. For tertiary channels, especially in the research area (including BPU $15 \mathrm{Ki}$ 1, BPU $15 \mathrm{Ki}$ 2, BPU $15 \mathrm{Ka}$, and BF $1 \mathrm{Ka}$ ), almost the entire channels are made of mounted stone. Figure 2 shows the top view of the study area, with the irrigation structures of BPU $15 \mathrm{Ki}$, BPU $15 \mathrm{Ki}$ 2, BPU $15 \mathrm{Ka}$, and BF $1 \mathrm{Ka}$. Figure 3 presents the conditions of the gates, demonstrating that the surrounding of gate $\mathrm{BF} 1 \mathrm{Ka}$ was full of trash. Figure 4 shows some cracks in several parts of the channels, as well as weeds growing on the channel banks. 
The sufficiency of the irrigation network as a means for delivering irrigation water to the field can be measured through the channel density (CD) and structure density (SD) of irrigation networks. CD is defined as channel length (m) divided by the served area (ha), and it can be considered as sufficient when $C D \geq 50 \mathrm{~m} / \mathrm{ha}$. Structure density, $\mathrm{SD}$, is defined as the number of structures divided by the total area of the paddy field. The structure density is considered to be sufficient when $\mathrm{SD} \geq 0.1$.

Information regarding the irrigation network in Sumber Rejo Village, including the channel length, land area, tertiary and quarterly boxes, and culverts, were obtained from the Punggur Utara Irrigation Area Office. Table 7 presents the density for the channels, and Table 8 shows the density of the structures. From the channel and structure densities presented in Tables 8 and 9, it can be said that the tertiary irrigation canal of BPU 15 at Sumber Rejo Village is inadequate both for channel and network densities.

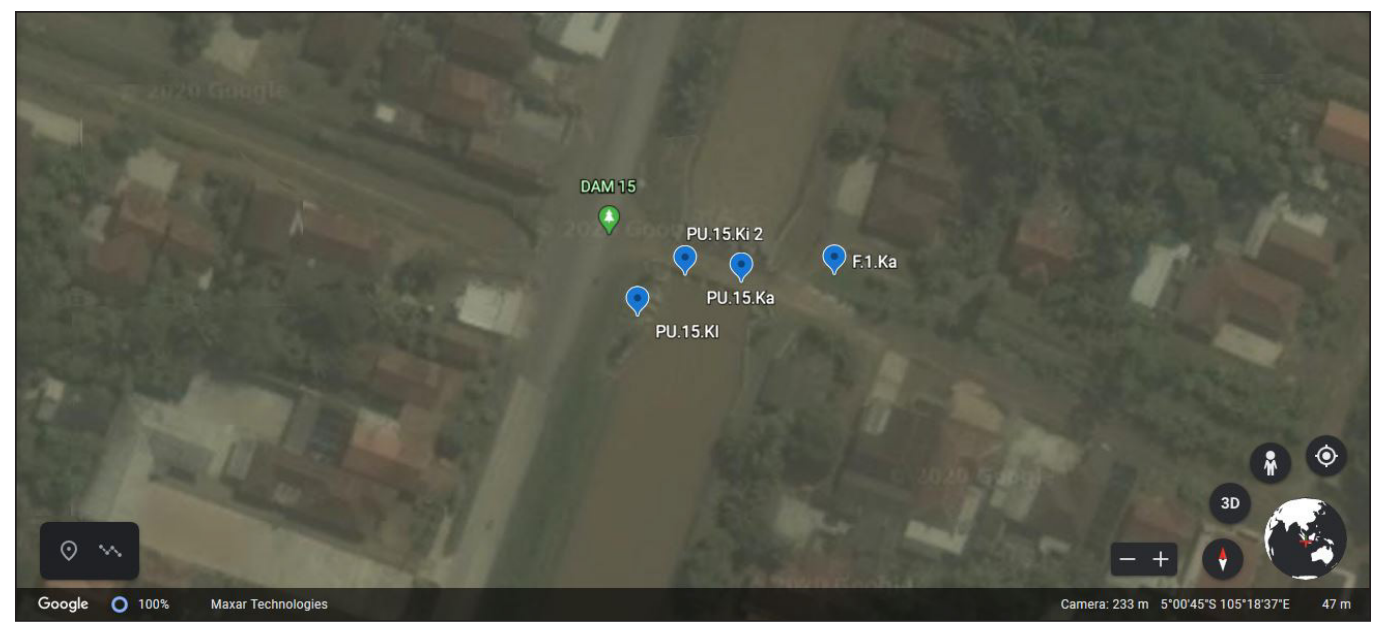

Figure 2. Top view of the study area, with the irrigation structures of BPU $15 \mathrm{Ka}$, BPU $15 \mathrm{Ki1}$, BPU 15 $\mathrm{Ki} 2$, and $\mathrm{BF} 1 \mathrm{Ka}$



(a)



(b)

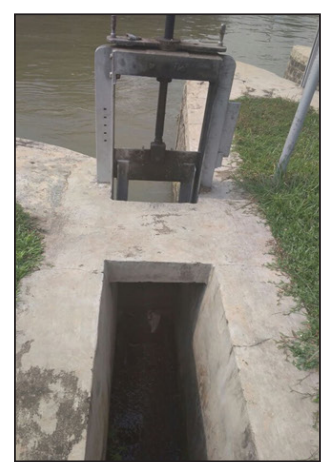

(c)

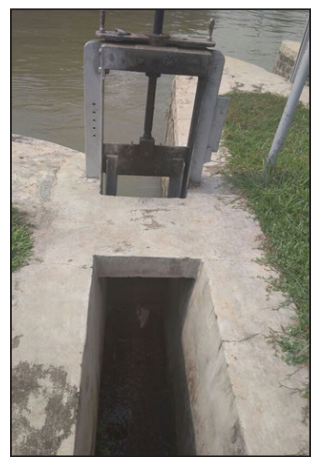

(d)

Figure 3. The gate conditions of (a) BPU $15 \mathrm{Ka}$, (b) BPU $15 \mathrm{Ki1}$, (c) BPU $15 \mathrm{Ki}$, and (d) BF $1 \mathrm{Ka}$ (from left to right respectively) in the Punggur Utara irrigation area at Sumber Rejo Village 


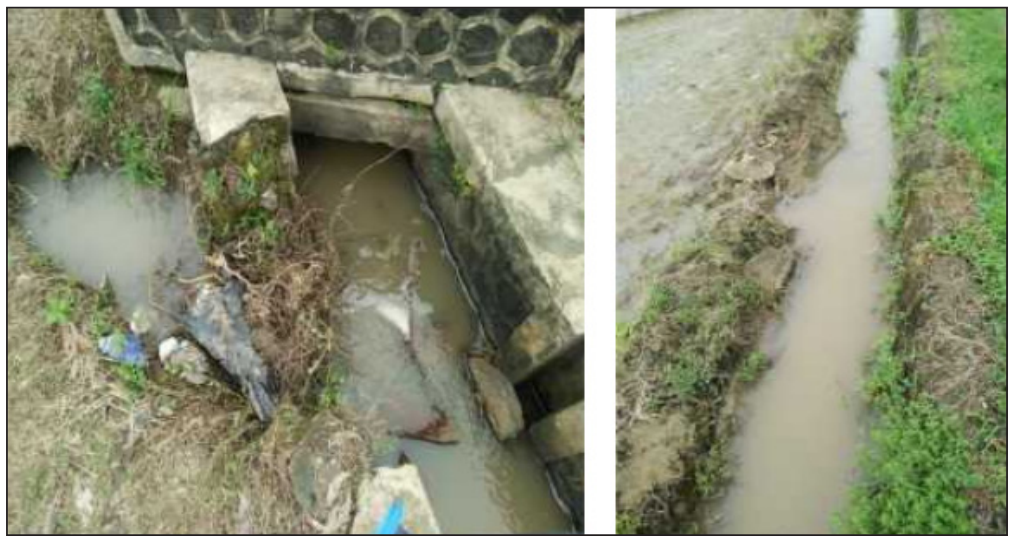

Figure 4. Channel conditions in the Punggur Utara irrigation area at Sumber Rejo Village

Table 7

Structures in BPU 15 Tertiary Canal at Sumber Rejo Village

\begin{tabular}{lcccc}
\hline \multirow{2}{*}{ Types of structures } & \multicolumn{4}{c}{ BPU 15 Tertiary Channels } \\
\cline { 2 - 5 } & BPU 15 Ki 1 & BPU 15 Ki 2 & BPU 15 Ka & BF 1 Ka \\
\hline Channel length (m) & 400 & 2100 & 2650 & 2015 \\
Potential area (ha) & 30 & 40 & 107 & 107 \\
Functional area (ha) & 25 & 45 & 73 & 98 \\
Tertiary Box (unit) & 1 & 2 & 4 & 2 \\
Quartery Box (unit) & - & 1 & 4 & 1 \\
Culverts (unit) & - & - & - & - \\
\hline
\end{tabular}

Table 8

The density of Tertiary Canal BPU 15 at Sumber Rejo Village

\begin{tabular}{lccccc}
\hline No & Channels & A (ha) & Channel length $(\mathbf{m})$ & CD (m/ha) & Remarks \\
\hline 1. & BPU 15 Ki 1 & 25 & 400 & 16 & Inadequate \\
2. & BPU 15 Ki 2 & 45 & 2100 & 46.67 & Inadequate \\
3. & BPU 15 Ka & 73 & 2650 & 36.30 & Inadequate \\
4. & BF 1 Ka & 98 & 2015 & 20.56 & Inadequate \\
\hline \multicolumn{7}{r}{} & Average & 29.88 & Inadequate \\
\hline
\end{tabular}

Table 9

The density of structures in BPU 15 At Sumber Rejo

\begin{tabular}{lccccc}
\hline No & Channels & A (ha) & Total boxes and culverts & SD (unit/ha) & Remarks \\
\hline 1. & BPU 15 Ki 1 & 25 & 1 & 0.04 & Inadequate \\
2. & BPU 15 Ki 2 & 45 & 3 & 0.07 & Inadequate \\
3. & BPU 15 Ka & 73 & 8 & 0.07 & Inadequate \\
4. & BF 1 Ka & 98 & 3 & 0.03 & Inadequate \\
\hline \multicolumn{7}{r}{} & Average & & 0.05 & Inadequate \\
\hline
\end{tabular}




\section{Statistical Analysis}

Correlation between variables was conducted using the Pearson product moment, and the regression statistics found that the $\mathrm{R}^{2}$ determination coefficient was 0.78 , which is greater than 0.22 , the Strongswan R table for a 5\% error level for the number of samples being 80 . This shows that there is a positive and significant relationship between the independent variables and dependent variables. It can be said that there is a significant influence between variables of age (X1), education (X2), total dependents (X3), farming experience (X4), land size (X5), farming income (X6), and group participation (X7) on water management (Y), amounting to $78 \%$, with the influence of variations outside the model being $22 \%$.

As there is a correlation between variables and a significant impact of the independent variables to the dependent variable, the next step was to perform multiple linear regression analysis to find the appropriate equation. Table 10 shows the result of this analysis. Based on the Table 10, we know that the P-value of variable X1 is 0.5411 larger than the critical confidence limit, which is 0.05 . This means that age, variable $\mathrm{X} 1$, has no effect on the variable of operations and maintenance $(\mathrm{Y})$. Omitting variable $\mathrm{X} 1$, but still using the result of multiple linear regression analysis, the Equation 1 becomes as follows:

$$
\mathrm{Y}=1.7377+0.72 \mathrm{X} 2+1.19 \mathrm{X} 3+0.76 \mathrm{X} 4+0.76 \mathrm{X} 5+0.74 \mathrm{X} 6+0.92 \mathrm{X} 7
$$

Table 10

Multiple linear regression

\begin{tabular}{ccccccc}
\hline \multirow{2}{*}{ Intercept } & Coefficients & Standard Error & t Stat & P-value & Lower 95\% & Upper 95\% \\
\cline { 2 - 6 } & 1.7377 & 0.7529 & 2,3081 & 0,0239 & 0,2369 & 3,2386 \\
\hline X1 & -0.1175 & 0.1914 & -0.6140 & 0.5411 & -0.4992 & 0.2641 \\
X2 & 0.7096 & 0.1572 & 4.5138 & 0.0000 & 0.3962 & 1.0229 \\
X3 & 1.1907 & 0.1873 & 6.3565 & 0.0000 & 0.8173 & 1.5641 \\
X4 & 0.7637 & 0.2102 & 3.6336 & 0.0005 & 0.3447 & 1.1827 \\
X5 & 0.7620 & 0.1617 & 4.7125 & 0.0000 & 0.4396 & 1.0843 \\
X6 & 0.7420 & 0.1732 & 4.2849 & 0.0001 & 0.3968 & 1.0872 \\
X7 & 0.9282 & 0.1466 & 6.3307 & 0.0000 & 0.5369 & 1.2205 \\
\hline
\end{tabular}

\section{Interpretation of the Results}

Based on the results of the study, all variables have a direct relationship to the irrigation management, which in this case, mostly related to the farmers' irrigation networks. However, of all these factors, age does not have a significant relationship or has a very low relationship. This is supported by the results of the validity test that found the age variable was invalid and the result of regression analysis, showing that the age variable has no effect on operations and maintenance activities. This means that regardless of age, 
farmers, both young and old, will be involved in carrying out operations and maintenance activities in the irrigation network.

The most influential variable on operations and maintenance activities is farmers' dependents (X3), being 1.19. This indicates that the greater the number of farmers' dependents, the more actively involved the farmers will be in operational and maintenance activities. Farmers who have more dependents are aware that the operation and maintenance of their irrigation network will have an impact on their farming and thus their economic situations. Thus, farmers with more dependents are willing to get more involved in operations and maintenance to meet their economic needs.

The next significant variable of the individual farmer on the activities in operations and maintenance is the land area variable (X5). This shows that farmers' land area determines farmers' involvement in operations and maintenance activities in the irrigation network. Farmers who have a larger land area will be more active in carrying out operations activities and maintenance of irrigation networks for the good of their farming. They will pay more attention to how the operating system works so that their land can be irrigated well, and farmers will often maintain their irrigation network, such as through cleaning trash and weeds from canals and repairing damaged channels.

Farming income (X6) presented in this study is the whole incomes of the farmers both from farming and non-farming. From all respondents, $61.25 \%$ have a low income, $26.25 \%$ have medium income and only $12.5 \%$ have a high income. Some studies show that participation in non-farming activities has a positive impact on household welfare by raising income levels (Ali et al., 2015; Zereyesus et al., 2017). However, there is a concern if non-farming activities generate much income, farmers may pay less attention to the operation and maintenance activities and even leave their farm. A study showed that there is social economic motivation for farmer to leave farming sector in Central Java, Indonesia (Farhani, 2009).

The constant of 1.7377 indicates that the level of the operations and maintenance performed by farmer members of WUA Harapan Maju is not considered good. This is based on the constant value obtained from the regression analysis, which is less than 2 . This value is based on the scoring of the answers in the questionnaire distributed to the respondents. The results of the evaluation of operations and maintenance activities based on respondents' answers are as follows:

- Existing irrigation networks are still not sufficient for the farmers. This is also supported by the results of the channel density, which has an average value of 29.88 . This value is below the standard of channel density ranging from 50 to $100 \mathrm{~m} / \mathrm{ha}$.

- Well-functioning irrigation structures are less than 50\%. This is also supported by irrigation structure density, which has an average value of 0.05 . This value is below the sufficient values of structure density ranging from 0.11 to 0.40 units/ha. 
- The irrigation water discharge is relatively small. By irrigating the land four to five times during one planting period, farmers feel that they have sufficient water. However, water distribution sometimes does not suit the predetermined schedule.

This study has shown that the operation and maintenance activities performed by the WUA farmer members in Harapan Maju was not good. Meanwhile, the results of the analysis show that both channel and irrigation structure densities are not met the common standards. The adequacy of the irrigation infrastructure seems to have effect on farmer participation in operation and maintenance. Therefore, if the government conducts such irrigation works in the future, so that the density of the structures and channels is sufficient (increased more in comparing to current status) farmers are expected to carry out the operation and maintenance activities better.

It is also suspected that poor operation and maintenance activities done by the farmers are also influenced by their low income. In the Government Regulation of the Republic of Indonesia No. 20/2006 (related to irrigation) it states that the participation of the farmer community should be in the form of contributions, orientation, time, energy, materials, and funds. As mentioned earlier, the majority of the farmer members (i.e. 61.25\%) have low income, so that they may not be able to contribute sufficiently in terms of funding for the operation and maintenance activities.

It becomes one of the recommendations of this study, that the government improves irrigation infrastructure especially the densities of channels and structures. In addition, to enhance the participation of farmers in irrigation scheme management, especially in operations and maintenance of hydraulic works, the government may provide incentives scheme to WUAs which capable of doing the operation and maintenance well. The incentives may be awarded periodically based on selection system at city/regency, province, or national levels.

\section{CONCLUSION}

Based on the characteristics of farmers joining in WUA Harapan Maju at Sumber Rejo Village, it can be concluded that the major motivations for being more active in irrigation management are the number of farmers' dependents and the land area owned by farmers. Interestingly, farmers' age does not have a significant relationship to irrigation management. Overall, the group participation of WUA Harapan Maju is "barely" adequate, although farmers' low activity levels regarding operations and maintenance can be shown by trash found near the irrigation gate and some unrepaired channels. The performance of irrigation management by WUA Harapan Maju at Sumber Rejo can be categorised as "barely" adequate and needs to be addressed. Irrigation management can be improved by getting farmers to participate more in operation and maintenance, as well as by improving the irrigation structures and networks. 


\section{ACKNOWLEDGEMENT}

The authors thank the Ministry of Research and Higher Education Indonesia for the funding through applied research scheme.

\section{REFERENCES}

Abernethy, C. L. (2010). Governance of irrigation systems: does history offer lessons for today? Irrigation and Drainage: The journal of the International Commission on Irrigation and Drainage, 59(1), 31-39. https://doi.org/10.1002/ird.552

Alaerts, G. J. (2020). Adaptive policy implementation: Process and impact of Indonesia's national irrigation reform 1999-2018. World Development, 129, 1-14. https://doi.org/10.1016/j.worlddev.2020.104880

Ali, A., Erenstein, O., \& Rahut, D. B. (2015). Impact of gender participation in non-farming activities on household income and poverty levels in Pakistan. Work, 52(2), 345-351. https://doi.org/10.3233/WOR152103

Azhar, A. W. M, Nashriyah, M., Hudzairi, H. R. M., Moneruzzaman, K. M., Amir, H. S., Rohaizad, M. R. M., \& Ali, A. M. (2014). Effects of irrigation frequencies on aerial agro-morphological parameters of Dioscorea hispida Dennst. (Dioscoreaceae). Journal of Applied Sciences Research, 8(9), 27-37. http:// dx.doi.org/10.2139/ssrn.2812557

Baldwin, E., Washington-Ottombre, C., Dell'Angelo, J., Cole, D., \& Evans, T. (2016). Polycentric governance and irrigation reform in Kenya. Governance: An International Journal of Policy, Administration, and Institution, 29(2), 207-255. https://doi.org/10.1111/gove.12160

Carracelas, G., Hornbuckle, J., Rosas, J., \& Roel, A. (2019). Irrigation management strategies to increase water productivity in Oriza sativa (rice) in Uruguay. Agricultural Water Management, 222, 161-172. https:// doi.org/10.1016/j.agwat.2019.05.049

Desrimon, A., \& Fiatno, A. (2018). Analysis of the impact of social, economic and group aspects of Water User Asscociation on operation and maintenance of irrigation network. Integrated Industrial Engineering Journal, 1, 46-54.

Dirwai, T. L., Senzanje, A., \& Mudhara, M. (2019). Water governance impacts on water adequacy in smallholder irrigation schemes in KwaZulu-Natal province, South Africa. Water Policy, 21(1), 127-146. https://doi. org/10.2166/wp.2018.149

Farhani, A. (2009). Socio economic motivation of farmers changing their job from farming sector to furniture industrial sector in Serenan village Juwiring district Klaten regency [Thesis]. Sebelas Maret University, Surakarta, Indonesia.

FAO. (2007). Irrigation management transfer: Worldwide efforts and results. Food and Agricultural Organization of the United Nations.

Fulazzaky, M. A. (2017). Participation of farmers in irrigation water management in Indonesia: A review. Irrigation and Drainage, 66, 182-191. https://doi.org/10.1002/ird.2085 
Gany, A. H. A., Sharma, P., \& Singh, S. (2019). Global review of institutional reforms in the irrigation sector for sustainable agricultural water management, including water users' associations. Irrigation and Drainage, 68(1), 84-89. https://doi.org/10.1002/ird.2305

Ghosh, S., Kolady, D. E., Das, U., Gorain, S., Srivastava, S. K., \& Mondal, B. (2019). Spatio-temporal variations in effects of participatory irrigation management (PIM) reform in India: A panel data analysis. Agricultural Water Management 222, 48-61. https://doi. org/10.1016/j.agwat.2019.05.042

Huamanchumo, J., Peñay, S. L., \& Hendriks, J. (2008). Developing capacity in water users' organisations: The case of Peru. Irrigation and Drainage 57, 300-310. https://doi.org/10.1002/ird.432

Hudzari, R. M., Syazili, R., Ssomad, M. A. H. A, Shokeri, A. F. M., \& Husin, N. A. (2016). Design and development of innovative highland water filtration system. World Journal of Engineering and Technology, 4, 383-390. https://doi.org/10.4236/wjet.2016.43037

Khalkheili, T. A., \& Zamani, G. H. (2009). Farmer participation in irrigation management: The case of Doroodzan dam irrigation network, Iran. Agricultural Water Management, 96(5), 859-865. https://doi. org/10.1016/j.agwat.2008.11.008

Letsoalo, S., \& Van Averbeke, W. (2004, November 8-11). When water is not enough: Institutions, organisations, and conflicts surrounding the sharing of irrigation water at a smallholder scheme in South Africa. In Proceedings of the Workshop on 'Water Management for Local Development', WRM (pp. 362-373). Loskopdam, Pretoria.

Mateos, L., López-Cortijo, I., \& Sagardoy, J. A. (2002). SIMIS: the FAO decision support system for irrigation scheme management. Agricultural Water Management, 56(3), 193-206. https://doi.org/10.1016/S03783774(02)00035-5

Meena, R. P., Karnam, V., Tripathi, S. C., Jha, A., Sharma, R. K., \& Singh, G. P. (2019). Irrigation management strategies in wheat for efficient water use in the regions of depleting water resources. Agricultural Water Management, 214, 38-46. https://doi.org/10.1016/j.agwat.2019.01.001

Mollinga, P., \& Bolding, A. (2004). The politics of irrigation reform. Ashgate Publishing.

Moustafa, M. M. (2004). Can farmers in Egypt shoulder the burden of irrigation management? Irrigation and Drainage Systems, 18(2), 109-125. https://doi.org/10.1023/B:IRRI.0000040249.12754.c8

Mukherji, A., Fuleki, B., Shah, T., Suhardiman, D., Giordano, M., \& Weligamage, P. (2009). Irrigation reform in Asia: A review of 108 cases of irrigation management transfer. International Water Management Institute.

Poddar, R., Qureshi, M. E., \& Syme, G. (2011). Comparing irrigation management reforms in Australia and India - A special reference to participatory irrigation management. Irrigation and Drainage, 60(2), 139150. https://doi.org/10.1002/ird.551

Rap, E. (2006). The success of a policy model: Irrigation management transfer in Mexico. Journal of Development Studies, 42(8), 1301-1324. https://doi.org/10.1080/00220380600930606

Sehring, J. (2007). Irrigation reform in Kyrgyzstan and Tajikistan. Irrigation and Drainage Systems, 21, 277290. https://doi.org/10.1007/s10795-007-9036-0 
Suhardiman, D., \& Giordano, M. (2014). Is there an alternative for irrigation reform? World Development 57, 91-100. https://doi.org/10.1016/j.worlddev.2013.11.016

Supriyadi, E. (2008). The relationship between group dynamics of Water User Association and maintenance of irrigation infrastructure in Polokarto District Sukoarjo Regency. [Unpublished dissertation]. Universitas Sebelas Maret, Surakarta, Indonesia.

Valipour, M. (2014). A comprehensive study on irrigation management in Asia and Oceania. Archives of Agronomy and Soil Science, 61(9), 1247-1271. https://doi.org/10.1080/03650340.2014.986471

Vandersypen, K., Keita, A. C. T., Lidon, B., Raes, D., \& Jamin, J. Y. (2008). Didactic tools for supporting participatory water management in collective irrigation schemes. Irrigation and Drainage Systems, 22(1), 103-113. https://doi.org/10.1007/s10795-007-9042-2

Zereyesus, Y. A., Embaye, W. T., Tsiboe, F., \& Amanor-Boadu, V. (2017). Implications of non-farm work to vulnerability to food poverty-recent evidence from Northern Ghana. World Development, 91, 113-124. https://doi.org/10.1016/j.worlddev.2016.10.015 
